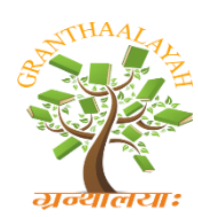

\author{
INTERNATIONAL JOURNAL OF RESEARCH - \\ GRANTHAALAYAH \\ A knowledge Repository
}

\title{
Social
}

\section{A CONDUCIVE ENVIRONMENT FOR THE IMPLEMENTATION OF THE ISLAMIC CRIMINAL LAW FROM THE PERSPECTIVE OF FIQH - A STUDY IN MALAYSIA}

\author{
Faisal Bin Husen Ismail ${ }^{* 1}$, Jasni Bin Sulong ${ }^{2}$ \\ ${ }^{* 1,2}$ School of Humanities (Islamic Studies), University Sains Malaysia, Malaysia
}

DOI: https://doi.org/10.29121/granthaalayah.v5.i4.2017.1799

\begin{abstract}
A conducive environment is a comfortable situation, harmonious as well as friendly in the relationship between government and communities upon enforcement of law. Therefore, the administration and enforcement of law towards society have to take account public's benefit, either from religion perspective, customary or local culture. The ignorance of those elements will bring regulation towards injustice and discrimination. For that reason, comfortable environment was taken into account during Caliph Omar al-Khattab who have procrastinated the enforcement of law (cutting hand for criminals) during drought period on the reason of unconducive period. It was a difficult phase of life which some communities living in needs and pitiable, and the situation is not appropriate to penalize them for stealing foods. However, scholars nowadays only discuss upon the matter in term of its influence to dismiss the application of Islamic law but not in term to comprehend the reality and concept of conducive environment in the application of Islamic criminal law. Therefore, the polemic of conducive environment took place without any yard stick of the situation that well elaborated. Hence, in order to overcome the conflict, this paper is at aim to clarify the notion as well as features of conducive environment from the perspective of shariah law. The paper will lay out the situation to become as a mechanism in measuring the readiness and ability in applying the fair law. The methodology of the study is in a qualitative means by reviewing historical notes by using content analysis upon the Prophets Era as well as the period of Khulafa' al-Rashidin. The data will be compared to contemporary epoch in understanding the similarity as well as the difference. The finding of the study is very significant to justify the appropriateness in the application of Islamic criminal law nowadays, whether its meet the need of shariah (maqasid al-shariah) or vice versa.
\end{abstract}

Keywords: Conducive Environment; Criminal Law; Hudud; Fiqh; Malaysia.

Cite This Article: Faisal Bin Husen Ismail, and Jasni Bin Sulong. (2017). "A CONDUCIVE ENVIRONMENT FOR THE IMPLEMENTATION OF THE ISLAMIC CRIMINAL LAW FROM THE PERSPECTIVE OF FIQH - A STUDY IN MALAYSIA." International Journal of Research - Granthaalayah, 5(4), 92-104. 10.29121/granthaalayah.v5.i4.2017.1799. 


\section{Introduction}

A conducive environment is always viewed as an ideal surrounding to realize the execution of certain tasks to be more organized and well-ordered in a community, where the necessities and comforts are in place. The convenience of environment is not only able to foster an excellent community in this world, where they manage to equip themselves with sufficient basic necessities of life, but it is also good for life in the hereafter where all the concerns and appreciation of ibadat are provided by the government (Anthony Reid 2015, 389).

A community's success and needs cannot be detached from effective legislation concerning the people. Hence, the legislation of criminal law is an important factor to produce a harmonious and peaceful community in security aspect for fulfilling the goals of Islamic laws. It becomes the agent of supervision to control overt behaviors of human beings for the purpose of unity as well as compliance of local's legislations and regulations. However, the implementation of criminal law cannot be done in frivolous, unless it is based on environment appropriateness, so that it can generate justice and equality in its judiciary. Thus, this study will discuss the forms of convenient and appropriate environment in which in today's understanding is widely known as a conducive environment.

\section{The Definition of Conducive}

According to Kamus Dewan (2004), conducive is defined as appropriate and beneficial to help, achieve or encourage in yield something. On the other hand, according to Kamus Besar Bahasa Indonesia, a conducive environment is a peaceful surroundings or can be simpler defined as a condition where there is no chaos, in which it supports the accomplishment of an activity or specific purpose. Yet, as mentioned by Oxford dictionary (2003), conducive means making something likely and possible. In general, based on these three sources, conducive environment signals positive connotation, guiding towards goodness, which can encourage the successfulness of an activity or goal that need to be accomplished.

From above description, a conducive environment can be explained from its physical viewpoint, which includes the aspect of nature, ecology, climate, etc. The same goes to politics, economy, knowledge and infrastructure that influence humans' developments and activities (Oluya: 1998). This situation yields special features of conducive environments, such as:

a) An environment that is appropriate and beneficial environment produce something

b) An environment that is peaceful (calm and comfortable) and not chaotic

c) An environment that encourages the successfulness of an activity

d) An environment that makes something likely and possible

Based on the above features, among the dominant factor that influences the existence of conducive environment are politics, economy, knowledge (Budiman Ginting: 2007) and infrastructure (M. Edi Hartono: 2009). Theoretically, there are three requirements of conducive environment, which are economic opportunity, political stability and legal certainty (Budiman Ginting: 2008). However, it is undeniable that there are still other factors that can influence an environment to be treated as conducive or vice versa. Thus, an environment is considered as 
being conducive if it fulfills at least four factors; politics, economy, knowledge and infrastructures.

\section{Conducive Environment for the Perspective of Fiqh}

In Islam, environment also plays vital role and legal consideration where the law and methods will shift when there are any changes in circumstances. For instance, the condition of war (AlQuran surah An-Nisa: 102) or illness will cause kaifiyat in performing prayer to be changed (Bukhari, no: 6744/7288). However, after the condition turns normal, the implementation of ibadah must be conducted as originally commanded. The adaptation of law according to circumstances can also be observed in the case of concession (rukhsah) where any changes in self-circumstances or environment may cause the changes on law towards individual as well as community.

Nonetheless, the granted law is not permanent, unless during the circumstance that is not appropriate to be implemented. As being stated in the method of "الضرورة تقدر بقدرها" (necessity is implemented by the extent thereof). This means a non-conducive environment can change the original prescribed law as long as it is under the non-conduciveness extent only. This indicates that the rules of Islamic law moves according to current circumstances or waqi'iyyah. The different circumstance or waqi' causes the law to be changed or abstained from being performed. For this reason, the scholars of usul also had been discussing about hindrance (al-mani) of the law from being enforced on someone (Abd al-Wahhab Khallaf: n.d). For example, the action of Ummar bin al-Khattab who did not impose any hudud punishment on thieves because there was a hindrance, which was the occurrence of the years of great famine ('am al-muja'ah) in the country. However, this hindrance was not denying the enforcement of criminal law to curb crimes from continuously taking place, where only heavy punishment such as hudud was not implemented to respect the non-conducive environment at that time.

As a conclusion, the religion of Islam certifies non-conducive circumstances as law variable where it is only based on the non-conducive states and must be implemented only on that particular time. After all, when the conducive environment is restored, then the original law must be performed as usual.

\section{The Implementation of Criminal Law in the History of Prophet Muhammad (PBUH)}

Based on the previous history of Prophet Muhammad (PBUH), the spread of Da'wah and the implementation of Islamic Sharia' upon Muslims were depending on the current issue at that particular time. Prophet Muhammad (PBUH) was sent to mankind to perfect good moral characters (Al-Bukhari:1997) and as a mercy to the world (Al-Quran, Al-Anbiya': 107), he also considered the perfect circumstances to implement the order of Allah SWT. Prophet Muhammad PBUH preached the Da'wah privately and publicly, which focused on the close relatives at the early stage. Prophet Muhammad PBUH encouraged Muslims to migrate to Madinah as the Quraish resisted the message of Islam. This migration also showed a conducive tolerance in the practice of preaching Da'wah. On the same page, Abdul al- Wahhab Khallaf (n.d) stated that, the stage of Da'wah in Mecca was more emphasized on the value of Aqidah and good moral 
characters, while the stage of Da'wah in Medina was more focused on worship, Jihad, and law which were more crucial and acquired greater commitment.

Islamic Sharia' was not being implemented without a strong development of Aqidah upon Muslims, specifically on the practice of certain penalty. Al-Quran and Al- Hadith have encompassed numerous practice of Sharia' which include imprisonment, caning, country withdrawing due to unlawful sexual intercourse for ghair muhsan (Al-Quran, An-Nisa':15-16) or stoning for muhsan (Al-Syawkani: n.d). Thus, the Islamic Sharia' was not being implemented till the establishment of Medina. According to Ahmad Rofiq (2001), Prophet Muhammad (PBUH) has implemented the punishment for those who committed fornication after the migration to Medina. Prophet Muhammad (PBUH) has implemented the punishment of stoning towards the Jewish who committed fornication in the month of Zulhijjah in the fourth year of Hijrah (AlZarqani: 1990). As stated by Jalaluddin al-Suyuti, according to the view of certain ulama', the punishment of stoning was the first stoning punishment that has been implemented in the Islamic history (Al-Suyuti: 1994).

Another event in Medina, Prophet Muhammad (PBUH) has implemented the stoning punishment after the declaration of a woman who has committed fornication with a Bedouin guy which based on the investigation of Unais (Muslim: n.d). It was also parallel to the stoning punishment towards Maiz bin Malik (Al-Albani: 2001) and a woman who came from the tribe of Ghamid (Ibid: 2001). This event occurred two years before the death of Prophet Muhammad PBUH which was in the ninth year of Hijrah (Ibid: 2001).

Furthermore, the punishment of hand cutting also has been implemented in the history of Prophet Muhammad (PBUH). The punishment of hand cutting has been done towards a woman who allegedly stealing which came from the tribe of Makhzum (Muslim:n.d). In fact, Prophet Muhammad PBUH was extremely mad on this matter as someone was requesting to bail the woman out from the punishment (Ibid: n.d). The hand cutting punishment also has been done by the Prophet Muhammad (PBUH) towards the act of stealing of one fourth Dinar or equivalent to three Dinar as recited by Aisyah, Ibnu Umar as well as Abu Hurairah (Ibid: n.d).

As stated by Anas bin Malik (Ibid: n.d), Prophet Muhammad (PBUH) has implemented the punishment of caning for 40 times towards those who drinks alcohol. Besides that, punishment of caning for 80 times has been done towards Misthah Binti Atatah, Hassan Bin Thabit and Hamnah Binti Jahsyi for launch a charge against chaste woman and not produce four witnesses to support their allegations (qazaf) towards Aisyah r.a ('Ali al-Husni al-Nadwi: 1998).

Prophet Muhammad (PBUH) was firm in dealing with the criminal offence as stated in the following situation:

\subsection{Political Environment}

Islamic government was the political entity established by Prophet Muhammad (PBUH) in Medina. There were numerous tribes in Medina which includes Tribe of Aus, Khajraj, and Jewish. However, the population of Muslims was greater compared to the local people which most of them convert to Islam and not worship idol any longer. At the same time, Jewish 
opposed against Islamic Government until they were involved in a few of the battles against Muslims which were Battles of Khandaq, Bani Mustaliq, Bani Nadir, Bani Quraidhah and Khaibar.

Apart from Jewish, Muslims also faced other threats from the military hypocritical which was led Abdullah bin Ubai Bin Salul. The withdrawal of 300 army from the group the military hypocritical in the Battle of Uhud in the fourth year of Hijriyah was such an obvious threat from them. Besides from the internal enemies, Muslims also were exposed towards external threats which were from Quraysh and the Roman government. The Battle of Badr occurred in the second year of Hijriyah, Battle of Uhud in the fourth year of Hijriyah, Battle of Khandaq in the fifth year of Hijriyah, Battle of Mu'tah in the eight year of Hijriyah and Battle of Tabuq in the ninth year of Hijriyah (Muhammad Abu Zahrah: 2008).

Based on the events mentioned shows that the political environment at that time was not fully stable as the Islamic Government continuously faced a number of threats from the enemies inside and outside of Medina. With the high population of citizen of Medina which involved diversity of ethnic and religion such as Muslims, Jewish, Majus, as well as other religion, Islamic Government of Medina continuously expanding in implementing the Islamic Sharia' at its best. Despite of facing massive threats, the implementation of Criminal Law in the history of Prophet Muhammad (PBUH) through many cases was made by himself as stated above.

\subsection{Economic Situation}

Economic development in Medina was mostly conquered by Jewish. Ali an-Nadwi (2009) estimated that there were 4400 of Jewish in Medina. Most of them were intelligent, owned huge and fertile farms as well as huge houses. Jewish from the tribe of Bani Qainuqa' expertized in managing money and gold. They controlled the economy of Medina because of their experts and money.

Apart from Jewish, Aus and Kharaj also among upper class people and owned farms. Such as, Sa`ad bin Rabi` who was became family with Abdul Rahman bin `Auf, who was among the richest man from the tribe of Aus ('Ali al-Husni al-Nadwi: 1998). Uthman Bin Affan also known as a successful businessman which as he contributed one fourth of his wealth to fund for the preparation of Battle of Tabuq which includes 1000 camels, 70 horses and 1000 Dinar (‘Ali alHusni al-Nadwi: 1998).

Besides of upper class, there were also middle class and also lower class people in Medina who were became homeless such as poor ahlu sufah who lived in Masjid Nabawi as they had no place to stay (Mohd Shukri Hanapi: 2012). Their poverty can be seen based on the story of Sahabah who had no sufficient amount of money to pay for the penalty (kafarah) for copulated with his wife during the day of Ramadan, thus Prophet Muhammad to him a few of dates. The man asked to him, "Do the other poorer people got the dates as well?", Prophet Muhammad replied: In the name of Allah, there were none of people from the South towards the top North of Medina who poorer from his family (Al-Bukhari: 1979). 
Based on the above situation, it was obviously explained the economic environment during the time of Prophet Muhammad (PBUH). Upper class, middle class as well as the lower class were existed in the city of Medina. The economy of Medina were controlled by Jewish which main focused on agriculture, construction, and also business.

\subsection{Knowledge}

In Medina, the competency of knowledge among local was different based on the ethnicity, standard of living and also religion. The religion was based on certain book of guidance such as Jewish who believes in Torah and Islam believes in Al-Quran as the book of guidance (Ahmad bin Hanbal: 1998). Argument, khutbah and also discussion were being held in the mosque or other places to spread the knowledge. In order to become competent in language, Prophet Muhammad (PBUH) has ordered Muaz Bin Jabal to learn Syriac and Hebrew languages as he worried other people might exaggerated on the letters that were sent by Prophet Muhammad PBUH to other leader of other tribes and country (Munir Muhammad al-Gadhban: 2011).

However, there were some of the nations at that time who had low competency of knowledge such as Bedouin who urinated in Masjid Nabawi (Al-Bukhari: 1979). The difference level of competency among citizen of Medina was influenced by many reasons such as the battle situation and live matters which restrain seek knowledge due to the time constrain. In fact, to spread the knowledge, Al-Quran encourages people to create a group who are interested and more focused on seeking knowledge (Al-Quran al-Taubah: 22). These types of situation showed a different level of competency among the citizen of Medina, which parallel to reality whereby there are those who are in high level of IQ, average level and also low level of IQ, as well as not educated and having low moral values.

\subsection{Infrastructure}

In terms of infrastructure, theoretically, the existence of facilities and basic need of living were fit for that particular time of Prophet Muhammad PBUH. The simplicity of infrastructure during the time of Prophet Muhammad (PBUH) can be seen where there was no appropriate court to hear the criminal offence as today. It was only being done in the mosque or other assembly area which could accommodate the nation to hear the criminal offence. In order to fulfill the role of judge, Prophet Muhammad (PBUH) will finalize certain case or other Sahaba who were been chosen by Prophet Muhammad (PBUH) to deal with certain cases at certain places. Such as, Prophet Muhammad has appointed Muaz Bin Jabal, Ali, as well as Abu Musa Al-Asyari as a Daei' which then become a judge in Yemen (Asadulloh Al Faruq: 2009).

Generally, during the time of Prophet Muhammad (PBUH), the infrastructure to support the criminal offence was simple. However, it was not become a hindrance to implement the criminal law during the time of Prophet Muhammad (PBUH).

\section{Situation During the Time of the Rashidun Caliphs}

The implementation of criminal law was continuously implemented during the rule of Rashidun Caliphs which were Abu Bakr, Umar, Uthman and Ali for approximately 30 years (11-40 
Hijriah). Among the implementation of criminal law was the effort of Abu Bakr to fight against those who reluctant to pay Zakat (Al-Bukhari: 1979). Besides that, during the time of Umar, the punishment of caning was implemented for 80 times towards those who drinks alcohol which occurred at that time (Ibn al-Jawzi: 2005). Next, there was an accusation towards Uthman, during the time of Uthman bin Affan who was being allegedly accused for ignoring the law of qisas towards Ubaidillah (the son of Umar bin Khattab) which killed Harmuzan who sought revenge for the death of his father (Rafiq al-Azm: 1968). However, according to Al-Tabari, Uthman has set the punishment of qisas towards Ubaidillah. Nonetheless, the family of Harmuzan has forgave Ubaidillah and reprieved the punishment of qisas on him (Al-Tabari: 1969). Furthermore, during the rule of Ali (Majid Raghib al-Helwa: 1980), the implementation of Islamic legislative was continuously implemented. For instance, Saidina Ali has ordered Muhammad bin Abu Bakr to punish a muslim guy who committed fornication with a Christian woman. Ali also wrote "Implement Hudud towards the muslim guy and hand over the woman to her religion to finalize the punishment on her behalf (Al-San`ani: 1983).

The above statement explained the implementation of criminal law in Islam was continuously fixed during the time of Rashidun Caliphs. The situation of the Criminal law during the time of Rashidun Caliphs was as follows:

\subsection{Political Situation}

The death of Prophet Muhammad PBUH has influenced the political situation in Medina at the early stage. According to Abu Zahrah (1991), the unstable political issue was started when there was a group of apostasy and the existence of fake prophet during the time of Abu Bakr (Wahhab al Najjar: 1990). However, during the time of Umar Al-Khattab, the situation in Medina could be controlled which help Umar conquered the area of Al-Jazira (Adimarwan Azwar Karim: 2006). During the rule of Uthman Ibn Affan, the political situation has become unstable for the second time. Uthman was killed due to the accusation of himself which was more focused towards nepotism during his rule. This conflict was continuously occurred until the rule of Ali. The political situation during the rule of Ali was The Battle of Siffin which involved Muawiyyah and Ali and the Battle of Jamal which involved Ali and Aisyah to seek for justice on the death of Uthman.

This situation explained the unstable political situation during the time of Rashidun Caliphs except during the time of Umar where the political situation was better in comparison.

\subsection{Economic Situation}

During the rule of Abu Bakr, the national economy was more manageable whereby the Baitulmal was established and the spoils (ghanimah) were collected and been divided among Muslims army. Furthermore, the wage systems towards government officer have been introduced (Afzalurrahman: 1995). Furthermore, the stable political environment influenced the betterment of national economy during the time of Umar. The non-owned agriculture lands have been passed over to Muslims as a reward, public market also has been built to enhance the national economy and the salary scheme also has been introduced to the army. 
However, there was a long drought season which affects the economy and people were suffered by this drought season. This situation fostered Umar to postpone the punishment towards the stealing offence at that particular time (Muhammad Husain Haekal: 2002). Despite of the postponement, the punishment still been done towards the individual who having doubt for the stealing offence of the poor theft. However, for the rich people who steal, they still got the punishment on their offence.

During the time of Uthman, the economy has become better due to the widening of the territory, greater wage from the zakat, tax (jizyah) as well as the spoils (ghanimah). At this time, the distribution of food towards the poor and travellers has been introduced. While during the time of Ali, the economy of the nation was not that good due to the political conflict during his rule. However, Ali spent the state money wisely. The highest contribution of Ali in enhancing the economy of the nation was the printing of the money of the Islamic government. (Tim Penulis P3EI UII Jogyakarta: 2009).

Above situation explained the economic environment during the time of Rashidun Caliphs which facing ups and downs thus affected the nation. There were people in upper class, middle class as well as the lower class. The lower class could receive zakat that was paid by the upper class to poor people and those who in need.

\subsection{Knowledge}

During the time of Rashidun Caliphs, the Islamic studies were still in decentralization. The spreading of knowledge was not being centralized, which no educational institution and school as the place to spread the knowledge. The spreading of knowledge was being done in the mosque or through discussion group by the qualified teachers .It was emphasized more on Al-Quran and Hadith and also a branch of knowledge which includes agriculture during the time of Umar AlKhattab. There was also educated people in Medina during that time such as Ali bin Abi Thalib, Abdullah Ibn Abbas, Abdullah Ibn Mas`ud, and Abdullah Ibn Umar. The Sahaba also were having discussion to discuss certain Islamic law.

However, there were a number of people who embrace Islam due to the conquest of new areas which trigger variety of questions to arise. This situation showed the different levels of Islamic knowledge of the Muslims at the particular area. This situation explained the situation of seeking knowledge during the time of Rashidun Caliphs. This also showed different levels of knowledge of Islamic studies among those who just new in Islam and who already embrace Islam for a long time.

\subsection{Infrastructure}

The conflict during the rule of Abu Bakr impeded the development of infrastructure. In fact, Abu Bakr not having an office. However, the infrastructure at this time was better than the time of Umar bin al-Khattab with the new nomination of al-Katib (government secretary), Nizamul Mal (minister of finance), Nizamul Idari (minister of administration). Besides that, Qadi (judge) has implemented the criminal law in order to hear the criminal offence (Muhammad Husain Haekal: 2002). This situation was continued in the time of Uthman and Ali. 
As the conclusion, the non-conducive environment in Medina was being influenced by the political conflict during the time of Rashidun Caliphs. This situation affected the economy, knowledge and also the infrastructure. There was a massive transformation of knowledge, economy and infrastructure during the rule of Umar.

\section{Conducive in Malaysia Today}

Since Malaysia was declared as an independent and sovereign country, changes continue to occur from the view of politics, economy, knowledge and infrastructure. The atmosphere changes as follow:

\subsection{Politics}

Malaysia consists of different races that are the Malays, Chinese, India, Kadazan and others. After independence, Malaysia faces with a number of critical situation like faced the attack from The Communist Party of Malaya (PKM) (Ho Hui Ling: 2015) until the Emergency Laws have been enforced on the 16 June 1948 in Ipoh area and Sungai Siput Perak and in Kluang Muar area, Kulai and Plentong in Johor (Federation of Malaya No 10 of 1948 in EM.s Ordinances and M.U, Ordinance). However on 18 June 1948 the Emergency Laws had been enforced on the whole of Malayan and been repealed by the authority on 31 July 1960 (Edgar: 1960). Besides the political environment between Malaysia and Indonesia was not harmonious but it was ended with a peace treaty on August 111966 (Hanta Yuda AR: 2010). Until now no major conflict has happened besides the invasion of the East Coast of Sabah on February 92013 by the Sulu Sultanate's Royal Soldiers and the Territorial Amy camp in Gerik Perak on the July 52000. Other cases like the Bersih Assemly and the demonstration after the arrested of Anwar Ibrahim 1998 but can be handled easily. In general up till now, after independence, the political environment in and outside Malaysia is under control from the threat from in and outside the country.

\subsection{Economy}

From the economy perspective, Malaysia gained national income from crops, taxed, tourism, industrial and others (Chor Foon Tang : 2015). The employment opportunities are adequate for the people. This is evidence by the large number of foreign workers come to Malaysia to find work, The Berita Harian reported that about 2.1 million foreign workers work in Malaysia now (Rahmah Ismail: 2016). In general the economy in Malaysia is growing from time to time. The good economic atmosphere will affect the income of the people. For example, the collection of zakat by the Zakat Centre of Pulau Pinang in 2006 which was about 28 millions ringgit and increased to 49 millions in 2010 and keep on increasing to 88 millions in 2015 (www.zakatpenang.com/statistik-kutipan)

The increase in the collection of zakat shows that an increasing number of individual's incomes community of Islam in this country. Even so the rich have not denied the existence of the poor in this country. 


\subsection{Knowledge}

From the knowledge perspective, Malaysia has a regular education system (Kementerian Pelajaran Malaysia 2012). To facilitate the knowledge learned, the educations ranging from kindergarten to universities have been established. The existence of madrasasas those are not formal like lodges study and maahad tahfiz contributed to the mobility of knowledge in Malaysia. The existence of the Education State Department and the Ministry of Higher Education are to facilitate the task of managing education in the country. Knowledge related to Islam such as the science of monotheism, fiqh and others can be learnt easily and comfortably. Now there are 20 universities and 54 private universities and colleges in the country. Nevertheless it is not deniable that there are those who do not have the opportunity to study because they are busy or other certain obstacles.

In general the development of education in Malaysia has create smart group even though there are still groups that do not have the opportunity to get education.

\subsection{Infrastructure}

From the point of infrastructure, Malaysia has developed it administrative for example to discuss an offence under the law; the court was created as a place to talk about Sharia court art (the criminal jurisdiction) 1965 amendments 1984). The judges and officials also have given a specific salary scheme (Musa Awang 2015) to facilitate the task of wiring, the constitution has empowered having the law of evidence and proof to the court. Generally infrastructure from the point of place, the court procedure, judges the laws relating to the court have been established in Malaysia.

\section{Condusive Environment: An Analysis of the Implementation of Islamic Law in Malaysia}

Based on the atmosphere that exited at the time of the prophet, the days of the government of Khulafa al-Rarsidin and the situation in Malaysia now, a comparison can be made:

\subsection{Political Environment}

As described above, there are similarities and differences in the political atmosphere during the Khulafa al-Rasyidin's government and in Malaysia from different perspective:

1) From the population, there were similarities between the Prophet Muhammad, Khulafa al-Rasyidin and the situation in Malaysia now. There are multiple life circumstances that occur between these three times. During the prophet time in Madinah, there were nomadic tribe of Arabic, Persian and Jews. At the time of Khulafa al-Rasyidin there were more tribes because the occurrence of the conquest in a remote area of Madinah. So also in Malaysia now consists of the Malays, Chinese, Indians and other tribes in the Malay Archipelago.

2) From the point of security, during the prophet Muhammad time and the Khulafa alRasyidin's government were often under threats of the enemies. The Jews, Quraisy, the Romans, Persians were the threats towards the Madinah Muslim government. While the 
situation and threats were not prolonged in Malaysia. Malaysia does not faced with threat to national security like the prophet Muhammad and Khulafa al-Rasyidin's time.

The above explanation shows that there are similarities and differences from the political view between the prophet's time, Khulafa al-Rasyidin and Malaysia now. Even now Malaysia enjoys the political situation more secure from threats both external and internal enemies when comparing to the prophet and Khulafa al-Rasyidin's time. To conclude, the political situation in Malaysia now is more conducive from the population and security views compared to the Islamic government during the Prophet Muhammad's time and Khulafa al-Rasyidin's.

\subsection{Economy}

There is some similarities between the prophet', Khalafa al-Rasyidin and Malaysia from the point of economic production. Agriculture, business, and crafts are types of occupations exist in these three times. From the economical standard angle, the rich society, the simpler and the poor are also exist in these three times. Nevertheless the economic is more conducive in Malaysia since the political condition is calmer in Malaysia compared to the prophet and Khulafa alRasyidin's times. The economic support is also strengthened by the many developed industries in Malaysia unlike during the prophet and Khulafa al-Rasyudin's time. This situation gives a sizeable income from the employment and national income. In conclusion the economic environment in Malaysia now is better compared to the economy of the Islamic society during the prophet and Khulafa al-Rasyidin's time.

\subsection{Knowledge}

There are similarities from the knowledge aspect between the time of the prophet Muhammad, Khulafa al-Rasyidin and Malaysia. The level of knowledge in these three times is not the same. There are people who are well educated and also people who are not educated at all. Nevertheless the level of knowledge in Malaysia is more equal compared to the prophet and Khulafa al-Rasyidin because its political and economy situation that are conducive. During the prophet and Khulafa al-Rasyidin's times, the education system still concentrated to the talaqqi method. Meanwhile in Malaysia now there are formal madrasah and non-formal madrasah as places for education and the well-developed curriculum so that the knowledge is easy to learn. The existence of information technology in Malaysia now further booth the spread of the knowledge. In other words the atmosphere of the knowledge in Malaysia is more conducive from the aspect of place, syllabus, the instructors provided are trained and equipped compared to the prophet and Khulafa al-Rasyidin"s times

\subsection{Infrastructure}

The existence of infrastructure was to make the administration of the Islamic criminal justice during the Prophet Muhammad's time was limited and it was bloomed during the Umar and Uthman's times. At first there was no infrastructure like the court or place where punishment was made. This situation was better during Umur's time and afterwards that led to realize the infrastructure for the matter of judgment. But then in terms of structure was not so neat. In Malaysia the existence of the court was to perform the duty of judgment. For example, to carry 
out the punishment, jails and the warders have created. In other words, the existence of infrastructure in Malaysia towards the criminal justice is more conducive compared to the prophet Muhammad and Khulafa al-Rasyidin's times.

\section{Conclusion and Proposal}

Conducive environment is a comfortable and suitable situation to implement laws. The conducive condition is needed to make all the laws including the criminal laws. Whereas the non-conducive can only be a reason for not implementing the criminal laws like Umar had postponed the execution of theft because it was a long drought season. This research found that the conducive condition is not the meaning of the absent and the chaotic politics, economics, knowledge and infrastructure of a society.

The study proposes to the Malaysian government that Malaysia has already met the characteristics. Malaysian government can do a preparation for the successful implementation of Islamic criminal legislation which gradually the course will take a period of time to be successful so that the level of life will be more equal and equitable like what is stated in the Rukun Negara. The conducive condition from the political, economic, knowledge and infrastructure support the establishment of the implementation of the criminal legislation in Malaysia.

\section{Acknowledgement}

This research was sponsored by Fellowship of University Sains Malaysia, Malaysia.

\section{References}

[1] Act Mahkamah Syariah (Criminal jurisdiction) 1965 (Amandments) 1984.

[2] Afzalurrahman. (1995). Doktrin Ekonomi Islam. Jogyakarta: PT. Dhana Bakti Wakaf.

[3] Al Faruq, Asadulloh. (2009). Hukum Acara Peradilan Islam. Yogyakarta: Pustaka Yustisia.

[4] Al Jawzi, Ibn. (2005). Jami` al-Masanid. al-Riyad: Maktabah al-Rusyd.

[5] Al Najjar, Wahhab. (1990). Al-Khulafa al-Rasyidun. Beirut: Dar al Kutub al-Ilmiyah.

[6] Al-Albani. (2001). Mukhtasar Sahih al-Imam Al-Bukhari. Al-Riyad: Maktabah al-Ma`arif.

[7] Al-Azm Rafiq. (1968). Asyhar Masyahir al-lslam fi al-Hurub wa al-siasah. Kaherah: Dar al-Fikr al-Arabi.

[8] Al-Bukhari. (1979). Al-Jami` al-Sahih. Kaherah: al-Matba`ah al-Salafiyah wa Maktabuha.

[9] Al-Bukhari. (1997). Sohih al-Adab al-Mufrad. Saudi Arabia: Maktabah al-Dalil.

[10] Al-Gadban, Munir Muhammad. (2011). Sababun fi al-'Ahdi al-Rasyidi. Kairo: Dar al-Salam.

[11] Al-Helwa, Majid Raghib. (1980). Al-Istifta` al-Sya`biy baina al-Anzimah al-Wadiyyah wa alSyariah al-Islamiyah. Kuwait: Maktabah al-Manar al-Islamiyyah.

[12] Al-Nadwi, `Ali al-Husni. (1998). Al-Sirah al-Nabawiyyah. Beirut: Dar Ibn Kathir.

[13] Al-San`ani. (1983). Al-Musannif. Al-Maktab al-Islami.

[14] Al-Suyuti. (1994). Tanwir al-Hawalik Syarh Muwatta' Malik. Beirut: Dar al-Fikr.

[15] Al-Syawkani. (n.d). Nail al-Autar Syarh al-Muntaqa al-Akhbar Min Ahadith Sayyid al-Abrar. Misr: Matba`ah Mustafa Babi al-Halabi.

[16] Al-Tabari. (1969). Tarikh al-Rusul wa Al-Muluk. Egypt: Dar al-Ma`arif.

[17] Al-Zarqani. (1990). Syarh az-Zarqani 'ala Muwatta`. Beirut: Dar al-Kutub Ilmiyyah.

[18] AS Hornby. (2005). Oxford Advanced Learner`s Dictionary. 7th edition, Oxford University Press. 
[19] Awang, Musa. (2016). Di Manakah Kita dalam Pemantapan Pentadbiran Keadilan Jenayah Syariah? Kanun (1), 55-84.

[20] Budiman Ginting. (2007). Hukum Investasi: Perlindungan Pemegang Saham Minoritas dalam Perusahaan Penanaman Modal Asing. Medan: Pustaka Bangsa Press.

[21] Budiman Ginting. (2008). Kepastian Hukum Dan Implikasinya Terhadap Pertumbuhan Investasi Di Indonesia. Medan: University of Sumatera Utara.

[22] Edgar O'balance. (1960). Malaya: The Communist Insurgent War, 1948-1960. London: Faber and Faber.

[23] Federation of Malaya No. 10 of 1948, dalam EM.s. Ordinances and M.U. Ordinance.

[24] Haekal, Muhammad Husain. (2002). Umar Bin Khattab. Diterjemah oleh Ali Audah. Jakarta: Litera AntarNusa.

[25] Hanapi, Mohd Shukri. (2012). Pembentukan Tasawur dan Kesan terhadap Pembangunan Tradisi Keilmuan Islam. International Journal of Islamic Thought. 2, 55-61.

[26] Hanbal, Ahmad bin. (1998). Musnad al-Imam Ahmad bin Hanbal. Beirut: Muassasah al-Risalah.

[27] Hanta Yuda AR. (2010). Menelusuri Konflik Indonesia-Malaysia. Dlm Update Indonesia. The Indonesia Institute Center For Public Policy Research, V (6), 2-12.

[28] Hartono, M. Edi. (2009). Hubungan Insentif Pajak Dengan Iklim Investasi Bagi Perusahaan Penanaman Modal Asing Di Sektor Industri Tekstil Di Indonesia. Jurnal Ilmu Administrasi Dan Organisasi, 16 (1), 8-12.

[29] Kamus Dewan. (2004). 4th Edition. Kuala Lumpur: Dewan Bahasa dan Pustaka.

[30] Karim, Adimarwan Azwar. (2006). Sejarah Pemikiran Ekonomi Islam. Jakarta: Rajawali Press.

[31] Kementrian Pelajaran Malaysia. (2012). Dasar Pendidikan Kebangsaan. Selangor: Giga Wise Network Sdn Bhd.

[32] Khallaf, Abd al-Wahhab. (n.d). Ilmu Usul al-Fiqh. Egypt: Maktabah al-Da`wah al-Islamiyah.

[33] Khallaf, Abd al-Wahhab. (n.d). Khulasah Tarikh al-Tasyri` al-Islami. Kuwait: Dar al-Qalam.

[34] Ling, Ho Hui. (2015). Gerakan Komunis Dan Pkm: Penelitian Terhadap Usaha Komunis Mempengaruhi Orang Melayu 1920-1989. Melayu: Jurnal Antarabangsa Dunia Melayu, 8 (1), 6392.

[35] Muslim. (n.d). Sohih Muslim. Beirut: Dar al-Fikr.

[36] Oluya, S.I, Oluburahimoh .H., Okege, O.O. (1998). Compendium of Issues in Citizenship Education in Nigeria. Ibadan: Pelcas Prints and Publishers.

[37] Reid, Anthony. (2015). Religious Pluralism or Conformity in Southest Asia`s Cultural Legacy. Studia Islamika. 22 (3), 387-404.

[38] Rofiq, Ahmad. (2001). Pembaharuan Hukum Islam di Indonesia. Yogyakarta: Gama Media.

[39] Sulong, Jasni \& Faisal Husen Ismail. (2011), Pemakaian Doktrin Al-Masalih Al-Mursalah Dalam Hukum Al-Fara'id. Jurnal Syariah, 19 (1), 1-22.

[40] Tang, Chor Foon. (2015). Penentu Makroekonomi Kadar Jenayah di Malaysia (Macroeconomic Determinants of Crime Rate in Malaysia). Jurnal Ekonomi Malaysia, 49 (2), 53-60.

[41] Tim Penulis P3EI UII Jogyakarta. (2009). Ekonomi Islam. Jakarta: PT Rajagrafindo Persada.

[42] Zahrah, M. Abu. (1991). Sejarah Aliran-Aliran Dalam Islam Bidang Politik dan Aqidah. Translate Drs. Shobahussurur. Gontor: Pusat Studi Ilmu dan Amal.

[43] Zahrah, M. Abu. (2008). Khatam al-Nabiyyin. Qaherah: Dar al-Fikr al-Arabi.

\footnotetext{
*Corresponding author.

E-mail address: jasni@usm.my
} 